национальных отношений, т.е. путь дальнейшей разработки и принятия пусть более узких, но зато глубоко проработанных федеральных законов, касающихся конкретных тем национальной политики.

Следует согласиться с тем, что федеральный закон об основах государственной национальной политики страны необходим. Идеи и концепции, приоритеты и цели, обозначенные Стратегией государственной национальной политики до 2025 г., руководящая роль ФАДН, принципы и механизмы его взаимодействия с публичными структурами различных уровней должны найти своё отражение в рамочном федеральном законе, который упорядочил бы и скоординировал усилия Федерации, её субъектов и муниципальных образований по реализации национальной политики. В федеральном законе также могли бы найти отражение формы участия граждан и общественных объединений в реализации национальной политики.

$$
\text { *** }
$$

1. Указ Президента РФ от 19 декабря 2012 г. № 1666 «О Стратегии государственной национальной политики Российской Федерации на период до 2025 года» // Собрание законодательства РФ. 2012. № 52. Ст. 7477.

2. Указ Президента РФ от 31 марта 2015 г. № 168 «О Федеральном агентстве по делам национальностей» // Собрание законодательства РФ. 2015. № 14. Ст. 2106.

3. Аваакьян С.А. Некоторые мысли о состоянии и перспективах конституционно-политического развития России // Вестник Московского университета. Серия 11. Право. 2016. № 1. С. 3-17.

4. Баринов И.В. Лицо уважаемой национальности // Российская газета. 2016. 23 сентября.

5. Баринов И.В. Термин «российская нация» не предполагает борьбу с инакомыслием // URL: http://fadn.gov.ru/news/2016/11/21/3020-termin-rossiyskaya-natsiya-ne-predpolagaet-borbu-s-inakomysliem (дата обращения: 10 декабря 2017 г.).

6. Болтенкова Л.Ф., Рябова Е.И. К вопросу о государственной национальной политике // Этносоциум. 2016. № 12 (102). С. 16-20.

7. Выступление доцента кафедры национальных и федеративных отношений РАГС при Президенте РФ А.Е. Жарникова о проекте Федерального закона «Об основах государственной национальной политики Российской Федерации» (по материалам «круглого стола») // URL: http://iam.duma.gov.ru/node/8/4427/14506 (дата обращения: 10 декабря 2017 г.)

8. Стенограмма заседания Совета по межнациональным отношениям и взаимодействию с религиозными объединениями при Совете Федерации на тему: «Совершенствование механизмов реализации государственной национальной политики Российской Федерации на период до 2025 года» // URL: http://www.council.gov.ru/events/news/67019/ (дата обращения: 10 декабря 2017 г.)

\title{
Цветков А.O. \\ Правовое положение военнопленных армии Карла XII пребывавших на территории России в период Северной войны (1700-1721гг).
}

doi: $10.18411 / \mathrm{j}-31-01-2018-40$

(Россия, Омск)

idsp: 000001:lj-31-01-2018-40

\section{Аннотация}

С формированием общего правового статуса личности неизменно получил развитие и специальный правовой статус, статус военнопленного. Параллельно с общеевропейским процессом становления правового положения военнопленного, в России развивалась собственная правовая традиция обращения с данной субъектной группой, которая имела характерную особенность, проявившуюся в период Северной войны (1700-1721гг). Этот опыт очень важен для истории военного плена и правового положения военнопленного, так как, впервые, России пришлось столкнуться с большим наплывом иностранцев, шведов, англичан, немцев которые в качестве военнопленных размещались в различных областях Российской империи.

Ключевые слова: Северная война, плен, военнопленный, правовой статус личности, особенности содержания в плену. 
Становление и развитие правового статуса иностранного военнопленного прошло длительный путь, от взгляда на военнопленного как на один из трофеев добытый войной, до признания его законным защитником своего отечества, наделением субъективными правами и обязанностями, связанными с реализацией правового положения военнопленного на территории государства противника. Сегодня, акты международного гуманитарного права призваны регулировать ход и методы ведения войны, отношения между участниками вооруженного конфликта их правовые статусы. Однако, наличие достаточно подробного закрепления правового статуса участников современного вооруженного конфликта не исключает проблем с реализацией международных правовых актов, устанавливающих данные статусы. В частности, особое внимание заслуживает реализация правового статуса наиболее уязвимой группы: военнопленного. Многочисленные материалы, представленные в СМИ, создают представление систематического попирания норм международного права в современных локальных войнах (Ирак, Украина, Сирия). Участники, демонстрируют не только открытое пренебрежение к действующему законодательству, но и отдаляясь от цивилизованного человечества на многие сотни лет, уходя в эпоху варварства, пыток, публичных казней. Именно признание в пленном личности и есть та главная задача, которая решалась несколько веков, прежде чем пришла к своему решению в виде норм международного и национального права.

В последнее время проблеме изучения пребывания военнопленных шведской армии на территории России уделяют недостаточно внимания. По данным РГБ среди крупных обобщающих работ по теме стоит отметить единственное диссертационное исследование, выполненное в 2003 году, Шебалдиной Галиной Викторовной: «шведские военнопленные в Сибири в первой четверти XVIII века». В нем подробно показаны особенности проживания, содержания, этапирования шведских военнопленных в Сибирь, отношение местных властей и народонаселения к военнопленным, режим содержания. В остальном тема представлена работами статейного характера носящих исторический или краеведческий уклоны. Представители юридической науки, к сожалению, на этом фоне малозаметны.

В историографии вопроса следует обратить особое внимание на работу дореволюционного ученого, юриста Александра Владимировича Лохвицкого (18301884гг.). Его магистерская диссертация неизвестна широкому кругу исследователей вопроса пребывания иностранных военнопленных на территории России. Между тем, в ней он впервые с научной точки зрения обобщил и проанализировал положение иностранного военнопленного на территории России, в том числе и в период Северной войны. Эта работа ценна еще и тем, что в ней автор использовал сведения недоступные современному исследователю уничтоженных временем или человеком. В своей магистерской диссертации «О пленных по древнему русскому праву» он приходит к значимому выводу о том, что в отношениях со Швецией факт гуманного обращения с военнопленными проявился особенно ярко. Из анализа работы А. В. Лохвицкого следует, что в период с XV по XVII вв. статус пленного находился под влиянием внешней политики России в отношениях с татарами, поляками, шведами и т. д. Наиболее прогрессивные отношения сложились с представителями Запада, в частности со Швецией. Этим во многом обусловливается привилегированное положение пленных шведов в России. Особенно в период правления Петра I военнопленные шведской армии, оставшиеся на службе своего нового отечества, получали право приобретения в собственность деревень с православными крестьянами. Православие не исключало плена само по себе, но определенным образом способствовало возможности быть освобожденным посредством обмена или выкупа и помогало избежать каких-либо дополнительных лишений. В результате эволюции, положение о выкупе не нашло 
развития, легитимность получил только обмен пленными между воюющими государствами.

Значимый вклад в исследование положения военнопленных шведской армии на территории России внес известный ученый, российский и советский историк Евгений Викторович Тарле (1874-1955гг.). Продолжая исследование положения военнопленных в период Северной войны, но уже в первой половине XX века, в своем труде: « Северная война: Северная война и шведское нашествие на Россию. Русский флот и внешняя политика Петра І» указывал, ссылаясь на мнение шведских историков, что «... пленных русских, захваченных в 1700 г., еще отправляли в Швецию на работы ( и держали там, прибавим, в таких условиях голода и жесточайших побоев, что выживали очень немногие), но уже взятых впоследствии в Польше, а особенно попавших в руки шведов во время нашествия на Россию в 1708-1709 гг., в плен очень часто не брали, а попросту убивали после сражения... Для шведов и их короля оказалось гораздо проще и короче связать русских пленников веревками, положив одного на другого по трое, и поразить эту живую груду тел штыком или саблей. Так было, например, после победы шведов при Фрауштадте (2 февраля 1706 г)». Принципиальная разница во взглядах на правовой статус военнопленного во многом обуславливается различием задач, которые ставили перед собой представители противоборствующих государств. Для России изначально было свойственно не преследовать цель физического уничтожения пленных противника. Захваченные иностранцы были нужны для перераспределения населения и привлечения на службу новых подданных, использования их умений и способностей. Для Швеции война с Россией носила завоевательный характер, поэтому Карл XII как военачальник естественным образом стремился нанести наибольший ущерб противнику, следовательно, в военнопленных, он видел, прежде всего, врагов, а не обезоруженных подданных другого европейского государства не оказывающих более вооруженного сопротивления, в обмен на жизнь.

Интересным для исследования вопроса представляется обращение к запискам современника тех событий, голландского исследователя, путешественника Корнелиия де Бруина. В частности, он указывает, что: «14 сентября 1702 года привели в Москву около восьмисот шведских пленных - мужчин, женщин и детей. Сначала продавали многих из них по три и по четыре гульдена за голову, но спустя несколько дней цена на них возвысилась до двадцати и даже тридцати гульденов. При такой дешевизне иностранцы охотно покупали пленных, к великому удовольствию сих последних, ибо иностранцы покупали их для услуг своих только на время войны, после которой возвращали им свободу. Русские тоже купили многих пленных, но несчастнейшие из них были те, которые попали в руки татар, которые уводили их к себе в рабы в неволю,- п положение самое плачевное». Тем не менее, данный пример скорее служит гротеском в отношении к шведским военнопленным, чем повсеместной реалией их положения. Продажа иностранных граждан в понимании современников имела неоднозначную оценку, об этом, в частности, можно судить по письму Петру I от патриарха Иерусалимского Досифея Второго (1641-1707).

За 60 лет до провозглашения в Европе основных прав военнопленных (после событий Великой французской революции), в России, уже существовали устойчивые правовые обычаи обращения с данной субъектной группой. Вопросам положения шведских военнопленных на территории России, их обеспечению, быту, социализации посвятил свой труд доктор исторических наук Дурова Ивана Герасимовича. Так основным элементом юридической конструкции было право военнопленного на жизнь. Всем пленным без исключения сохраняли жизнь, не подвергали пыткам, коллективным наказаниям и иным методам воздействия с целью осуществить террор среди военнопленных, чтобы привести к максимальному физическому уничтожению. Следующий немаловажный элемент - право на достойное проживание на территории противника соответственно воинскому званию и занимаемой должности в собственной 
армии. Это элемент реализовывался через выделение как собственных средств шведского правительства, как, впрочем, и русского, на содержание своих подданных на территории другого государства. Довольствие, военнопленные шведской армии получали наравне с чинами русской армии. Эта позиция очень важна, так как указывает на главнейший принцип государственной политики в отношении правового положения личности ответственность за своего подданного, на территории враждебного государства. Стоит отметить, что такая позиция невпервые встречается в литературе и правовых документах посвященных истории и формированию военного плена на территории России. А.В. Лохвицкий отмечает, что выкупом своих граждан у иноплеменников Российское государство занималось еще со времен Золотой Орды. Сбор денег носил характер пожертвований, которые делали все слои общества. Основным меценатом выступала церковь и служилые люди. Полоняничный приказ ведавший сбором денежных средств на выкуп своих земляков у иноплеменников прекратил свое существование только при Екатерине II. Для улучшения собственного благосостояния военнопленные имели право на труд, т.е. заниматься ремеслом, что позволяло не только обеспечивать себя ежедневно продовольствием, но и формировать определенные материальные запасы. Свобода в выборе занятия (ремесла) принадлежала офицерам. Младшие чины обязаны были работать и активно привлекались Петром I на строительство оборонительных объектов. Некоторым офицерам за личные заслуги устанавливались персональные выплаты. Еще одним важным элементом, входящим в юридическую конструкцию правового статуса иностранного военнопленного в период Северной войны, стала возможность проживать со своей семьей. Данная привилегия касалась только офицеров. Семья получала содержание за счет государства в сумме равной половине оклада мужа по должности. Проживание военнопленных было в казармах. По окончании войны правовой статус военнопленных упразднялся, и они могли выбирать, остаться им на территории нового государства или вернуться к себе на родину.

Из анализа приведенного материала следует, что шведским военнопленным были гарантированы основные права иностранного военнопленного, а их реализация позволяла им не только выжить, но и многим из них обрести в России новое отечество. В целом, мнение о том, что содержание шведских военнопленных в России было удовлетворительным не находит существенных расхождений, среди исследователей. Процесс адаптации к новым условиям жизни в плену во многом складывался и обуславливался местом военнопленного в воинской иерархии. Соответственно, чем выше было его место, тем менее тяжелыми для него были последствия пленения, и чем ниже, тем более тягостно ощущалось пребывание в плену. В состав юридической конструкции правового статуса военнопленного пребывавшего на территории России входили такие элементы как право на жизнь, труд (для офицеров) его же можно отнести и к обязанностям (для нижних чинов), свобода переписки, вероисповедания, заключения межконфессионального брака. Следует пояснить, что юридическая конструкция правового статуса личности шире, чем конструкция правового статуса военнопленного и соотносится между собой как целое и часть. Задача законодателя при формировании элементов юридической конструкции правового статуса военнопленного обеспечить минимум необходимый для поддержания жизнедеятельности в плену для значительной массы иностранцев оказавшихся на территории России в силу обстоятельств вызванных войной. В целом следует заключить, что заинтересованность молодого Российского государства в перемене вынужденного народонаселения на постоянное, была прямая, так как в плен, попадали бывшие рабочие, служащие, чьи знания и умения были очень нужны государству в отсутствии собственных ресурсов подорванных войной. Такого рода привилегии можно охарактеризовать практической особенностью выраженной в качественном восполнении утраченного народонаселения, численного заполнения территории России, привлечения наиболее способной категории бывших иностранных 
подданных на службу новому отечеству. Обращение к опыту Северной войны, в частности к военнопленным во многом помогает понять последующую нормативную правовую особенность формирования положения данной субъектной группы в международном и отечественном законодательстве в последующие периоды военной истории.

$$
* * *
$$

1. Источник № 1 Организация Объединенных Наций и международное гуманитарное право URL: http://www.un.org/ru/humanitarian/law/geneva.shtml (дата обращения: 01.12.2017).

2. Источник № 2 Харьков новостное агенство URL: https://nahnews.org/987784-zverstva-igil-v-palmireterroristy-chudovishchno-izdevalis-nad-plennymi-boicami-saa (дата обращения: 01.12.2017);

3. Источник № 3 Free News информационно-аналитический портал URL: http://freenews.su/proisshestviya/25132-boeviki-ig-sozhgli-plennogo-sirijskogo-pilota (дата обращения: 01.12.2017);

4. Источник № 4 Русская весна URL: http://rusvesna.su/news/1499070562 (дата обращения: 01.12.2017).

5. Источник № 5 Шебалдина, Г.В. шведские военнопленные в Сибири в первой четверти XVIII века: дис. ... канд. ист. наук: 07.00.02.. М., 2003. 272с.;

6. Источник № 6 Сибирский Вавилон: шаедские узники в начале XVIII B. // URL: http://elar.urfu.ru/bitstream/10995/36628/1/qr_4_2015_12.pdf (дата обращения: 11.01.2017).

7. Источник № 7 Размещение шведских военнопленных в Подмосковье (конец 1705-середина1709гг) // можайское историческое общество URL: https://kukovenko.ru/istoricheskie-materialy/shvedskievoennoplennye-v-podmoskove (дата обращения: 04.01.2018).

8. Источник № 8 Шведские военнопленные в Москве /l pikabu URL:https://pikabu.ru/story/shvedskie_voennoplennyie_v_moskve_4491337 (дата обращения: 04.01.2018);

9. Источник № 9 "Свой-чужой" шведские военнопленные в Сибири // Путь в Сибирь URL: http://library.ikz.ru/georg-steller/aus-sibirien-2013-2006/shebaldina-g.v.-201csvoi-2013-chuzhoi201d2013 (дата обращения: 04.01.2018);

10. Источник № 10 Шведы в Санкт-Петербурге // невский проспект URL: http://nevskiprospekt.ru/id2/id-4.html (дата обращения: 04.01.2018);

11. Источник № 11 Тысячи шведов в Сибири: как восток встретился с западом // ОМСКАЯ ЗЕМЛЯ общещственный проект URL: http://omsk.land/history/tysyachi-shvedov-v-sibiri-kak-vostok-vstretilsyas-zapadom/ (дата обращения: 04.01.2018).

12. Источник № 12 Лохвицкий, Александр Владимирович О пленных по древнему русскому праву (XV, XVI, XVII века). Исследование. М., 1855. 104 с.

13. Источник № 13 Тарле, Евгений Викторович Северная война: Северная война и шведское нашествие на Россию. Русский флот и внешняя политика Петра І. . М.: Астрель, 2010. С. 701.

14. Источник № 14 Журнал Петра Великого. ч.І изд. СПб.: 1770. С. 134. Цит. по: Тарле, Е.В. Северная война: Северная война и шведское нашествие на Россию. Русский флот и внешняя политика Петра I. М.: Астрель, 2010. С. 124-125.

15. Источник № 15 Корнелий, де Бруин Путешествие через Московию Корнилия де Бруина. М.: 1873. Глава Х.С.99.

16. Источник № 16 Чтения в Императорском Обществе истории и древностей Российских. Книга вторая под изд.Барсова Е.В. М.: Университетская типография, 1891. С. 59.

17. Источник № 17 О положении российских и шведских военнопленных в период Северной войны 1700-1721 гг. // Военно-исторический журнал URL: http://history.milportal.ru/2014/07/o-polozhenierossijskix-i-shvedskix-voennoplennyx-v-period-severnoj-vojny-1700-1721-gg/\#more-5505 （дата обращения: 16.12.2017.).

18. Источник № 18 Дуров, Иван Герасимович О положении российских и шведских военнопленных в период Северной войны 1700-1721 гг. // Военно-исторический журнал URL: http://history.milportal.ru/2014/07/o-polozhenie-rossijskix-i-shvedskix-voennoplennyx-v-period-severnojvojny-1700-1721-gg/\#more-5505 (дата обращения: 16.12.2017).

19. Источник № 19 Шведские военнопленные времён Северной войны 1700-1721 гг. // подмосковный краевед URL: http://trojza.blogspot.ru/2013/03/1700-1721.html (дата обращения: 22.12.2017). 